\title{
An Investigation of the English Vocabulary Knowledge of Lower Secondary Students: A Case Study of a Malaysian School
}

\author{
Noor Syahira Noor Mayadi1 iD. $\triangle$, Hamidah Yamat² iD \\ ${ }^{1}$ Faculty of Education, Universiti Kebangsaan Malaysia, Bangi, Selangor, Malaysia \\ ${ }^{2}$ Associate Professor, Faculty of Education, Universiti Kebangsaan Malaysia, Bangi, Selangor, Malaysia \\ $\triangle$ Corresponding Author: Noor Syahira Noor Mayadi, E-mail: syahiramayadi@gmail.com
}

\section{ARTICLE INFORMATION ABSTRACT}

Received: December 17, 2020

Accepted: February 22, 2021

Volume: 3

Issue: 2

DOI: $10.32996 /$ ijels.2021.3.2.14

\section{KEYWORDS}

Vocabulary Level, Lower

Secondary, English Language

Learner, CEFR
This preliminary study aimed to investigate the vocabulary level of lower secondary students in Kedah, specifically in a school located at a sub-urban area. The purpose was to gather the base data for a study on the effectiveness of using audio-visual materials in enhancing students' vocabulary. In this preliminary study, quantitative approach was employed to identify the vocabulary level of the secondary school students. The samples consisted of 30 Form 1 students from a sub-urban school in Kepala Batas, Kedah, Malaysia. A vocabulary checklist was used to identify their knowledge of vocabulary and a vocabulary test was used to identify their vocabulary levels. The finding of this study shows that the students are at intermediate level on vocabulary knowledge. Based on this finding, the researcher will be able to conduct a suitable activity according to the students' vocabulary knowledge for the study on the effectiveness of using audio-visual materials in enhancing students' vocabulary.

\section{Introduction}

Learning English Language especially in a community whose mother tongue is not English poses a great challenge to the students. This is because, not only they have to master the four language skills which are listening, reading, speaking and writing, they also need to have a good knowledge and mastery of the language's grammar and vocabulary. In fact, vocabulary is vital in any language learning as without vocabulary, the other skills as well as the language aspects cannot be mastered.

In Malaysian education system, English Language is a very important subject. The objective of having English as one of the main subjects taught in school is to ensure and enable all school leavers to use English in their daily life. It is also because most information on the internet is in English Language so this will help students to access them easily as being stated in Dokumen Standard Kurikulum dan Pentaksiran Tingkatan 3 (April, 2018):

"As English Language is also dominantly used in Information and Communications Technology (ICT), pupils need to master it to enable them2 to have easy access to information that is available via the electronic media such as the Internet. Besides, it is paramount that pupils equip themselves with the necessary skills in order to keep pace in a rapidly emergent global economy as indicated in the Malaysian Education Blueprint 2013-2025."

It is also well known that English has become a language of communication around the world. According to the recent statistics, English has been the official language in 55 sovereign states and 27 non-sovereign entities. Even many country subdivisions have also declared English an official language at the regional or local level (Rao, 2019). Knowing and understanding English will be a huge help to the students in order for them to be updated with the current issues around the globe or in their studies. Thus, having wide knowledge on vocabulary will be a huge advantage for them as they will be able to comprehend the language better.

When the students who are the second language learners learn English, the students should master all the language skills. However, in order to master all the four skills, students must have strong vocabulary mastery. Undeniably, vocabulary is much

K C AL-KINDI CENTER R FOR RESEARCH AND $R$ DEVELOPMENT Your gateway to world-class research

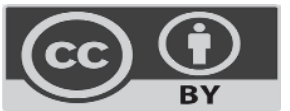

Published by Al-Kindi Center for Research and Development. Copyright (c) the author(s). This open access article is distributed under a Creative Commons Attribution (CC-BY) 4.0 license 
more than grammar, it is the key to children to understand what they hear and read in schools; and to communicate successfully with other people (Rojas, 2015). If the students do not have wide vocabulary, it will become a hindrance for them not only in spoken communication but also written communication. We can still understand the language even if the correct grammar is not used. On the other hand, the language will tell us nothing if we know nothing about vocabulary (Gasma, 2017).

Thus, this study is conducted on a group of students by using quantitative approach in order to measure the vocabulary level of the lower secondary school students. Based on their overall performances in their English Language examinations, 83 students or $51.875 \%$ of the total students in Form 1 of a school in Kepala Batas, Kedah, Malaysia failed their mid-year examination. They were not able to perform well especially in the writing section. This is because they cannot express their thoughts and idea as they do not have sufficient amount of vocabulary. By doing this research, it is hoped that their level of vocabulary knowledge can be identified. This will then help teacher in planning lessons which are suitable for their level especially during the current Covid19 pandemic situation where schools are closed due to Movement Control Order (MCO). Other than that, from this research the base data for a study on the effectiveness of using audio-visual materials in enhancing students' vocabulary can be gathered.

\section{Literature Review}

\subsection{Vocabulary Acquisition and Learning}

Vocabulary is words used in a particular language. A language user needs to have vocabulary knowledge in order to convey the meaning while communicating to others. Vocabulary knowledge refers to knowledge of word meanings, but entails more than the acquisition of word meanings as isolated units (Hwang et al, 2019). According to Alqahtani (2015), there are two kinds of vocabulary which are Receptive Vocabulary and Productive Vocabulary.

Receptive vocabulary (vocabulary refers to all the words in a person's language repertoire) refers to words that a person can comprehend and respond to, even if the person cannot produce those words (Burger and Chong, 2011). The receptive vocabularies can be grasped by language learner in their daily live through spoken language which are from daily conversations or from any media such as television and radio. Besides that, they can also learn new receptive vocabularies through written language such as newspaper, blog entries, novels, magazines and many more. Sometimes, a language learner is not even aware of the new vocabularies that they have learned daily. However, the language learners may not be able to produce or to utter the words. On the other hand, productive vocabulary knowledge assumed as the words that are understood and can be pronounced by the learners (Maskor and Baharudin, 2016). This means that the language learners are able to use the vocabularies that they have acquired in their daily conversation through spoken or written conversation. They are aware of the vocabulary and they can use it in correct situation to convey the correct meaning.

According to the study by Boonkongsean, (2012), the factors affecting students' vocabulary learning strategy can be divided into three categories which are learner individual difference, social and situational factors and learners' learning outcomes. The learners individual difference includes learners believe, attitude, motivation and language learning experience. Similarly, a different study also mentions motivation as one of the factors. The result shows that nearly ninety percent of the respondents express that the most important reason for learning English is to pass the examination in the classes. Results of study show that students with stronger motivation participated in self-initiated learning activities than did the less motivated $(\mathrm{Wu}, 2013)$. These two studies show that one of the most important factors that is affecting students' vocabulary learning is their own motivation. If they are motivated in learning, they will have their own desire and will to master this aspect of language learning.

Harjit et al (2015) found out that is crucial to address the issue of limited vocabulary knowledge prior to their tertiary education. Their research shows that the undergraduate students have inadequate vocabulary knowledge in their secondary education level which will then affect their tertiary level of education. In another study among Year 5 primary students, Wang and Yamat (2019) found out that majority of the participants have yet to master the English vocabulary according to the standard set by the Malaysia Standard-Based Curriculum English syllabus. When the students have not mastered the language according to the standard, this will give effect to their studies in the future. This can be related to the research that have been mentioned previously. If the students fail to master the vocabulary, they may face hardships when they further their studies. Some of the obstacles that they will face are related to their overall academic success and influence their writing quality (Mokhtar et al, 2010).

\subsection{CEFR Vocabulary Assessment and Resources}

Students start learning English formally when they enroll into Primary school and Secondary school. They have to study the language for at least 11 years before furthering their studies in tertiary education. The widely used benchmark in determining one's proficiency in English for the purpose of admission into tertiary institutions is the Malaysian University English Test (MUET) (Rethinasamy and Chuah, 2011). This means that in order to pursue their studies in local universities, students must sit for an English Language test which is known as MUET. The students will be tested on four language skills which are reading, writing, speaking and listening. The scores from these four tests will be accumulated, graded and students will be given a certificate. 
Some tertiary institution also makes it compulsory for their students to learn English if they failed to achieve certain standard in MUET. Thus, it is important for students to prepare themselves from their early age if they are planning to further their stu dies to the higher level.

Common European Framework of Reference or CEFR was established in the 1990s. In 2017, the Ministry of Education Malaysia have introduced the new syllabus for English Language which is known as Common European Framework of Reference (CEFR). This is a also a step to familiarise and prepare the students for MUET. For students in Secondary Level, this new syllabus was introduced starting with Form 1 students. At that time, the students in Form 2 to Form 5 continued with the old KSSM (Kurikulum Standard Sekolah Menengah) syllabus. For this new CEFR syllabus, a new textbook was chosen to be used to accompany students in their learning process which is Pulse 2. Up to this year in 2020, the new CEFR syllabus has been cascaded and are currently being used by students in Form 1 to Form 4. Every year, new textbooks are being introduced to accommodate the new syllabus in each of the secondary school level. By 2021, all students in Form 1 to Form 5 should be taught by using CEFR in their syllabus and the Form 5 students in 2021 will be the first batch to sit for their SPM (Sijil Pelajaran Malaysia) with CEFR syllabus.

The CEFR descriptors are being divided into six levels which are A1 \& A2 for Basic User, B1 \& B2 for Independent User and C1 \& C2 for Proficient User. The description for each level is as follow:

\begin{tabular}{|c|c|c|c|}
\hline \multirow{2}{*}{$\begin{array}{c}\text { Proficient } \\
\text { user }\end{array}$} & C2 & Mastery & $\begin{array}{c}\text { General description } \\
\text { figh proficient - can use English very } \\
\text { fluently, precisely and sensitively in } \\
\text { most contexts }\end{array}$ \\
\cline { 2 - 4 } & C1 & $\begin{array}{c}\text { Effective } \\
\text { Operational } \\
\text { Proficiency }\end{array}$ & $\begin{array}{c}\text { Able to use English fluently and } \\
\text { flexibly in a wide range of contexts }\end{array}$ \\
\hline $\begin{array}{c}\text { Independent } \\
\text { User }\end{array}$ & B2 & Vantage & $\begin{array}{c}\text { Can use English effectively, with } \\
\text { some fluency, in a range of contexts }\end{array}$ \\
\cline { 2 - 4 } & B1 & Threshold & $\begin{array}{c}\text { Can communicate essential points } \\
\text { and ideas in familiar contexts }\end{array}$ \\
\hline Basic User & A2 & Waystage & $\begin{array}{c}\text { Can communicate in English within a } \\
\text { limited range of contexts }\end{array}$ \\
\cline { 2 - 4 } & A1 & Breakthrough & $\begin{array}{c}\text { Can communicate in basic English } \\
\text { with help from the listener }\end{array}$ \\
\hline
\end{tabular}

Table 1: CEFR descriptors

As having a wide vocabulary mastery helps in better communication, CEFR has also stressed on vocabulary aspects. English Vocabulary Profile (EVP) is one of the resources in English Profile which is a long term, collaborative programme of interdisciplinary research whose goal is to transpose the Common European Framework of Reference for the English language (CEFR; Council of Europe 2001) and for teaching and assessment purposes where English is the language being learned (Anon, 2011). EVP can be accessed online by language users where they can search for the meaning of vocabulary in the EVP. Other than providing the meaning for each of the vocabularies, language users can also listen to the correct pronunciation of the word. The CEFR level for each of the word is also provided in the EVP.

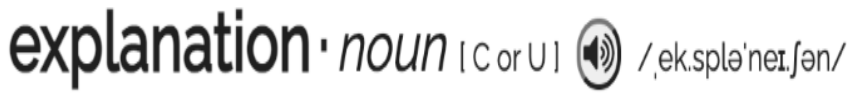

\section{+Word family}

\section{+ explanation}

B1 the details or reasons that someone gives to make something clear or easy to understand

Figure 1 : English Vocabulary Profile (EVP) 
Vocabulary is an aspect that is highlighted in the current syllabus. The DSKP (Dokumen Standard Kurikulum dan Pentaksiran) contains list of words that are repeated within the textbook which are the suggested vocabularies suitable for students. The words are listed either based on textbook unit or by category. Students are not expected to learn all these words by heart, or to spell all of them with $100 \%$ accuracy; although good accuracy in spelling is a requirement at A2 level, complete accuracy in spelling is above the A2 target in CEFR (DSKP Bahasa Inggeris Tingkatan 1, 2017). Teachers are free to choose words that are not in the list or to omit some words from the list if necessary. Teachers are also advised to consult additional vocabulary resources such as the English Vocabulary Profile (EVP) when they want to choose the suitable vocabulary for their lessons. Other than the EVP, teachers can also refer to the Cambridge English: Vocabulary List. By the end of lower secondary level which is in Form 3, students are expected to reach the B1 level of CEFR. In order to achieve this, students should know or master the vocabularies that are listed in the DSKP.

\section{Methodology}

\subsection{Research Design}

This preliminary study employs quantitative approach to identify the vocabulary level of the secondary school students.

\subsection{Instruments and Materials}

The instruments and materials that were used in this study are Vocabulary Checklist, Vocabulary Test and a scoring sheet. The vocabulary checklist consists of 300 words that students should know to achieve B1 level in CEFR. CEFR is Common European Framework of Reference which is a new type of assessment criteria used to evaluate students' English level of proficiency in Malaysia. The vocabulary checklist is to identify their knowledge of vocabulary which indicates the words that they know. As for the vocabulary test, students are required to give the meaning of the words in the vocabulary checklist. This is to identify whether the students know the actual meaning of the words and have vocabulary mastery. All the scores from the vocabulary checklist and vocabulary test are recorded in a scoring sheet.

\subsection{Participants}

The sample was 30 Form 1 students of a school located in Kepala Batas, Kedah. The total population of Form 1 students in this school are 160 students. However, due to the limited access because of the Movement Control Order (MCO) period whereby all schools were closed, only 90 students were able to be contacted from which only 30 students were willing to participate. Thus, only 30 sample were able to be obtained for this research. Convenience sampling method was used when samples were chosen.

\subsection{Data Collections}

During the study, the students went through a few processes in order to check on their level of vocabulary. The types of data that were collected are from the vocabulary checklist and also the scores that they get in the vocabulary test. Vocabulary checklist was given to the students at the beginning of the study to check on the number of vocabularies that the students are familiar with. The checklist consists of 300 words that were taken from the expected list of vocabularies for B1 level from CEFR. The words were chosen randomly from all the vocabularies for B1 level of CEFR. The scores for this activity were recorded and tabulated in the scoring sheet. The total score for this activity is 300 .

After that, the students answered a vocabulary test. The test consists of 300 words that were on the vocabulary checklist that the student had answered previously. In this vocabulary test, students are required to give the synonyms of the words or explain the meaning of the words correctly. They are allowed to give the meaning in English and also in their own mother tongue which is Malay Language. This is to make sure that the students can really differentiate the meaning. All the words prepared are based on the vocabulary level for B1 of CEFR. This is because by the end of their lower secondary studies or when the students reached Form 3 or 15 years old, they are expected to achieve B1 level of CEFR. The score from this test is also recorded and tabulated in the scoring sheet. In order to collect all the data, teacher checked the students score for the vocabulary checklist and vocabulary test. All the answer samples were collected and kept by the teacher to be analysed and graded by percentages (\%).

\subsection{Research Context}

The target population are Form 1 students. The school is situated in a sub-urban area where the students have minimum exposure to English Language in their community. The community living in this area are mostly villagers who works as farmers, lorry driver, grocery store owners and some government servants. Other than that, they are usually exposed to the language only during lessons in school with their English Language teacher. The minimum exposure leads to unfamiliarity to the language. Thus, the target vocabulary level of all the students is from lower intermediate to intermediate level of vocabulary.

All of the samples are at the age of 13 years old and they are all Malay. The students have limited amount of vocabulary because of their background which hinders them from participating in the English Language lessons. As a result of this, they always lose their focus in class and do not show any interest during lesson because they are not able to understand the lesson. 


\subsection{Validity and Reliability}

To ensure the validity and reliability of the instruments and materials used, the researcher chose all the words tested from the list of vocabulary in CEFR which are in B1 level. As being mentioned earlier, B1 is the level that students should achieve when they achieve when they reach Form 3 level or 15 years old. Thus, in order to prepare them to achieve the targeted level of CEFR, students should be familiar with all the words in the vocabulary list. Other than that, the questions chosen for the Vocabulary Test are also adapted from the current CEFR textbook which is Pulse 2. This is to ensure that the questions are within the topic and theme that students are taught in their classroom.

\section{Results and Discussion}

In order to measure the vocabulary level of the students, data were collected and analysed from the vocabulary checklist and vocabulary test score. The vocabulary checklist was given to the samples at the beginning of the study to check on the number of vocabulary that each of the samples are familiar with. The number of vocabularies that they chose also represents the number of vocabularies that the samples recognized. The scoring for vocabulary checklist is divided into three categories which are lower vocabulary level, intermediate vocabulary level and advanced vocabulary level. The samples who score between $0-100$ is identified to have lower vocabulary level, those who scored between 101-200 are identified to have intermediate vocabulary level while those who scored between 201-300 are identified to have advanced vocabulary level. From the vocabulary checklist, $16.67 \%$ samples were in lower vocabulary level, $66.66 \%$ samples were in intermediate vocabulary level and $16.67 \%$ were in advanced vocabulary level.

\begin{tabular}{|c|c|c|c|}
\hline Score & $\begin{array}{c}\mathbf{0 - 1 0 0} \\
\text { (Low) }\end{array}$ & $\begin{array}{c}\mathbf{1 0 1 - 2 0 0} \\
\text { (Intermediate) }\end{array}$ & $\begin{array}{c}\mathbf{2 0 1 - 3 0 0} \\
\text { (Advanced) }\end{array}$ \\
\hline No. of Samples & $5(16.67 \%)$ & $20(66.66 \%)$ & $5(16.67 \%)$ \\
\hline
\end{tabular}

Table 2: Vocabulary Checklist scores

From the results of the vocabulary checklist, we can see that majority of the samples are in the intermediate vocabulary level with the total number of 20 out of 30 samples. This also equals to $66.66 \%$ which is the majority within these samples. The remaining number of samples have the same percentage is $16.67 \%$. The results obtained from this vocabulary checklist cannot be the only way of measuring the vocabulary level of the students. This is because this result only represents the number of vocabularies that the samples are familiar with. The samples may have heard or come across the vocabularies in their daily life but may not know the meaning and usage of the vocabulary. Thus, the vocabulary test was also done following the vocabulary checklist.

Next is the vocabulary test. As being mentioned earlier, the results of the vocabulary checklist cannot be the only indicator to determine student's vocabulary level. Thus, the vocabulary test was conducted to make sure that the samples have really mastered the word. In this test, samples are required to give the synonyms or meaning of the words that they have ticked in the vocabulary checklist. If they are able to give the synonyms or meaning of all the words that they have chosen, that shows that the samples have mastered the word.

The scoring is also divided into three categories. The first category is for lower vocabulary level where samples need to score between 0-100 marks. The next category is between 101-200 marks is in intermediate vocabulary level while those who scored between 201-300 is considered in the advanced vocabulary level. In this test, $33.33 \%$ samples are in lower vocabulary level, $53.33 \%$ samples are in intermediate vocabulary level while $13.33 \%$ samples are in advanced vocabulary level.

\begin{tabular}{|c|c|c|c|}
\hline Score & $\begin{array}{c}\mathbf{0 - 1 0 0} \\
\text { (Low) }\end{array}$ & $\begin{array}{c}\mathbf{1 0 1 - 2 0 0} \\
\text { (Intermediate) }\end{array}$ & $\begin{array}{c}\mathbf{2 0 1 - 3 0 0} \\
\text { (Advanced) }\end{array}$ \\
\hline No. of Samples & $10(33.33 \% \%)$ & $16(53.33 \%)$ & $4(13.33 \%)$ \\
\hline
\end{tabular}

Table 3: Vocabulary Test scores

On contrary to the results from the vocabulary checklist, we can see that more the number of samples who achieve intermediate and advanced level decreased. On the other hand, the number of samples who achieve low level increase. The samples were not able to explain the meaning or synonyms of the words. This shows that the samples were not able to master the vocabulary. The results also shows that although the samples already have prior knowledge of the words tested, they were not able to use the words in the proper context as they are not familiar with the meaning and use of the word. 


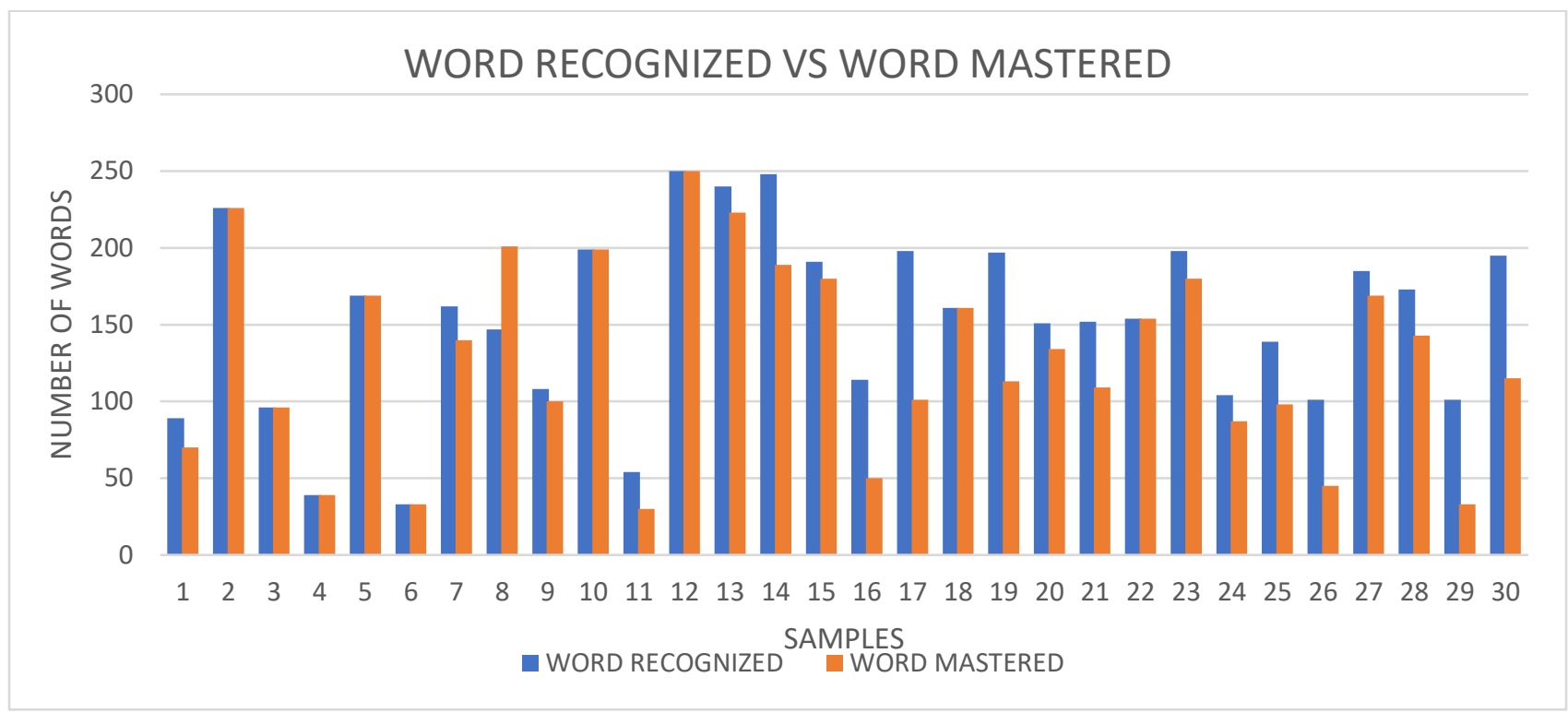

Figure 2: Comparison between vocabulary recognized and number of words mastered

From the vocabulary test, only eight samples (26.67\%) were able to explain the meaning of words or give synonyms for the words that they have chosen in the vocabulary checklist. This shows that they have mastered the vocabulary. The remaining 22 samples (73.33\%) were not able to do so. This shows that although they recognized the words listed in the vocabulary checklist, they do not know the meaning or the synonyms of the words. For example sample number 17 recognized 198 words from the checklist. However, he only managed to master only 101 out of 198 words which is $51.01 \%$ from the words that he recognized. Same goes with sample number 30. He was only able to master 115 (58.97\%) out of 195 words that he recognized in the vocabulary check list.

The results from the Vocabulary Test shows that the students have not mastered the vocabulary tested. As being mentioned earlier, $73.33 \%$ of the samples were not able to master all the words that they have recognized. This shows that they have come across the words in their daily life for example from their readings or from the shows that they watch on the television. However, although they recognized the words, they were not able to master it. This may be because they have not been taught specifically about the words that they have recognized. This also shows that the students do not have productive vocabulary level because productive vocabulary knowledge assumed as the words that are understood and can be pronounced by the learners (Maskor and Baharudin, 2016).

Students should master their vocabulary since their school years in order to help them in when they further their studies to higher level. In the research by Harjit et al (2015), the results shows that it is crucial to address the issue of limited vocabulary knowledge prior to their tertiary education. Their research shows that the undergraduate students have inadequate vocabulary knowledge in their secondary education level which will then affect their tertiary level of education. Thus, this research is one of the steps that could help in fixing the issue. The students' level of vocabulary identified in this study will help teachers in preparing them with suitable activities in class. This will hopefully help students' in mastering the vocabularies required according to the standard.

\section{Conclusion}

This study is conducted on a group of students in order to measure the vocabulary level of the lower secondary school students. The result of this study shows that the level of vocabulary for the students in this school is at the intermediate level. The students might be aware of the words or vocabulary listed in the vocabulary checklist as they may have heard them during lesson or from their daily activities or surroundings such as from radio or television shows. However, they might not know the actual usage or meaning of the words that they have heard of. Besides that, some of the students may have heard the word and are only familiar with the pronunciation of it. Unfortunately, they are unaware of the spelling and meaning of the word. That might be the reason why it is difficult for them to retain the vocabulary that they have learnt. Thus, it reflects on the results of their Vocabulary Test whereby only $13.33 \%$ of the students are in the advanced vocabulary level.

After conducting this research, the researcher had identified a few limitations in this study. There were a few problems faced by the researcher while doing this study. One of the limitations is that this study was done in a very short time which was only 
within two weeks. This was because of the time constraint. The researcher started off by giving a vocabulary checklist to the students. In the following week, the researcher gave a vocabulary test to the students. The vocabulary test was only done once with the students. Thus, it makes this study could not be done to the maximum. The study may have identified a better result if it was done in a longer period of time. Other than that, the researcher can also give a few vocabulary tests to the students to ensure that the results that are obtain is more reliable and valid.

Next, the implementation of the study process was less smooth. This was because there were times that the students do not want to cooperate during the study. This was especially because the study was done online because of school closure due to Covid-19 pandemic. All the vocabulary checklist and vocabulary test were given to the students via online platforms such as WhatsApp group application and Google Forms. Some of the students ignored the test given. According to Bahasoan, Ayuandiani, Mukhram, \& Rahmat (2020), this learning still has some weaknesses, including signals that are difficult to reach by students who live in the area, a lot of chat that makes the cell phone memory full so that the internet connection is slow and quite tiring because they have to go back and forth to see the chat from the beginning of learning. If this study was done in the classroom, the researcher will be able to monitor the students and they will be able to make sure that all the students in the classroom participate in the study. However, since this was done at home, the researcher can only give reminders to the students through online applications, text messages and phone calls. Thus, the number of participants of this research are only 30 students which only represents around $18.75 \%$ of the total population.

Other than that, since the vocabulary checklist and vocabulary test was given via online platforms such as WhatsApp group and google form, the researcher cannot ensure that the students do all of the activities on their own without any help from their family members. This is because the researcher could not monitor them while they are doing the activities. The students answer both Vocabulary Checklist and Vocabulary Test at home through Google Form. Links were given to them via WhatsApp. Some of the students share the mobile phone with their parents. Therefore, there are possibilities that the students may have answered it by asking their siblings or parents. They may have also referred to dictionaries for meaning of the words before answering the Vocabulary Checklist and Vocabulary Test. It would be better if all the procedures could be done in classroom to avoid these problems. However, this situation was unavoidable because of the pandemic that is happening around the word which is Covid19 which causes school closure.

Thus, it can be concluded that the limitation of this study was mainly because it was conducted during the Covid-19 pandemic. The Movement Control Order (MCO) that was enforced around Malaysia had forced school closure. As a result, the research could not be done in classroom settings which leads to limitations such as short research period, students' cooperation in the research and the researcher cannot ensure that students took part in all of the activities without any help from their family members and other learning tools such as dictionaries and gadgets. It is suggested that this research should be done in classroom to overcome the limitations listed.

Funding : This research received no external funding

Conflicts of Interest: The authors declare that there are no conflict of interest.

\section{References}

[1] Alqahtani, M. (2015). The importance of vocabulary in language learning and how to be taught. International journal of teaching and education, 3(3), 21-34. https://www.iises.net/international-journal-of-teaching-education/publication-detail-213?download=2

[2] Anon (2011, August). English Profile : The CEFR for English. University of Cambridge.https://languageresearch.cambridge.org/images/pdf/theenglishprofilebooklet.pdf

[3] Bahasoan, A. N., Ayuandiani, W., Mukhram, M., \& Rahmat, A. (2020). Effectiveness of online learning in pandemic COVID-19. International Journal of Science, Technology \& Management, 1(2), 100-106. https://ijstm.inarah.co.id/index.php/ijstm/article/view/30/18

[4] Boonkongsaen, N. (2013). Factors affecting vocabulary learning strategies: A synthesized study. Naresuan University Journal: Science and Technology (NUJST), 20(2), 45-53. http://www.journal.nu.ac.th/NUJST/article/view/6/7

[5] Burger A., Chong I. (2011) Receptive Vocabulary. In: Goldstein S., Naglieri J.A. (eds) Encyclopedia of Child Behavior and Development. Springer, Boston, MA. https://doi.org/10.1007/978-0-387-79061-9_2359

[6] Dokumen Standard Kurikulum dan Pentaksiran Bahasa Inggeris Tingkatan 1 Kurikulum Standard Sekolah Menengah. https://drive.google.com/file/d/1LewKaOPdUQkkx7obZO-9VwL66QB6oB8A/view?usp=sharing

[7] Gasma, Y. (2017). The Implementation Of English Song In Teaching Vocabulary At The First Grade Of Senior High School. https://docs.google.com/viewer?url=http\%3A\%2F\%2Fdigilib.unila.ac.id\%2F26812\%2F12\%2FSKRIPSI\%2520TANPA\%2520BAB\%2520PEMBAH ASAN.pdf

[8] Harji, M. B., Balakrishnan, K., Bhar, S. K., \& Letchumanan, K. (2015). Vocabulary Levels and Size of Malaysian Undergraduates. English Language Teaching, 8(9), 119-130. https://files.eric.ed.gov/fulltext/EJ1075488.pdf

[9] Hwang, J. K., Mancilla-Martinez, J., McClain, J. B., Oh, M. H., \& Flores, I. (2020). Spanish-speaking English learners' English language and literacy skills: The predictive role of conceptually-scored vocabulary. Applied psycholinguistics, $41(1), 1$. https://www.ncbi.nlm.nih.gov/pmc/articles/PMC7117096/ 
[10] Wu, L. F. (2013). A study of factors affecting college students' use of ESL vocabulary learning strategies. International Journal of Humanities and Social Science, 3(19), 202-208. http://www.ijhssnet.com/journals/Vol_3_No_19_November_2013/25.pdf

[11] Maskor, Z. M., \& Baharudin, H. (2016). Receptive Vocabulary knowledge or productive vocabulary knowledge in writing skill, which one important. International Journal of Academic Research in Business and Social Sciences, 6(11), 261-271.

https://www.researchgate.net/profile/Zunita-

Maskor/publication/310461986_Receptive_Vocabulary_Knowledge_or_Productive_Vocabulary_Knowledge_in_Writing_Skill_Which_One_Impo rtant/links/582e8e7408ae138f1c01dd18/Receptive-Vocabulary-Knowledge-or-Productive-Vocabulary-Knowledge-in-Writing-Skill-WhichOne-Important.pdf

[12] Mokhtar, A. A., Rawian, R. M., Yahaya, M. F., Abdullah, A., Mansor, M., Osman, M. I., ... \& Mohamed, A. R. (2010). Vocabulary Knowledge of Adult ESL Learners. English Language Teaching, 3(1), 71-80. https://files.eric.ed.gov/fulltext/EJ1081453.pdf

[13] Rethinasamy, S., \& Chuah, K. M. (2011). The Malaysian University English Test (MUET) and its use for placement purposes: A predictive validity study. Electronic journal of foreign language teaching, 8(2), 234-245. https://papers.ssrn.com/sol3/papers.cfm?abstract_id=2146007

[14] Rao, P. S. (2019). The role of English as a global language. Research Journal of English, 4(1), 65-79. https://www.rjoe.org.in/Files/vol4issue1/new/OK\%20RJOE-Srinu\%20sir(65-79).pdf

[15] Rojas, A.S.E . (2015). The use of songs to increase the learning of the english vocabulary among seventh year students, in parallel $A$ at Pompilio Reinoso Jaramillo educational center, during the school year 2013-2014.

https://docs.google.com/viewer?url=http\%3A\%2F\%2Fdspace.unl.edu.ec\%2Fjspui\%2Fbitstream\%2F123456789\%2F15292\%2F1\%2FAndrea\%2 520Stefan\%25C3\%25ADa\%2520Elizalde\%2520Rojas.pdf

[16] Wang, F., \& Yamat, H. (2019). Identifying English Vocabulary Levels of Malaysia Year 5 Primary School Students. International Journal of Academic Research in Business and Social Sciences, 9, 62-76.

https://pdfs.semanticscholar.org/b95e/89f9887de1de677f669f0ba4dcfba3836838.pdf 